\title{
22. 往復ヘリカルCTシステムの検討
}

\section{Examination of Shuttle Helical CT System}

\author{
(株)東芝・那須工場 C $\mathrm{T}$ 技術部 $\bigcirc$ 粉川智恵子 南部恭二郎松林孝行 \\ 東芝メティカルエンシニアリング (Chieko Kogawa) (Kyojiro Nambu) (Takayuki Matubayashi) \\ + (Noriyuki Oshima) \\ 藤田保健衛生大学病院并田義宏山本明人

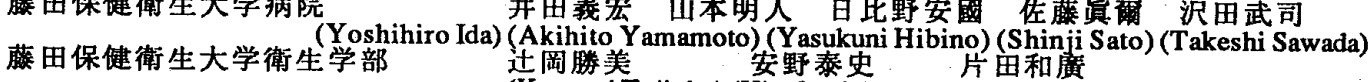 \\ (Katsumi Tujioka) (Hirofumi Anno) (Kazuhiro Katada)
}

\section{【目的】}

ダイナミックヘリカルCTの開発の一環として、往復へリ カルCTシステムを開発し、基本性能揖よび臨床での可能性 について検討した。往復へリカルCTは、1回の呼吸停止下で X線を連続曝射しながら休止時間0で寝台を往復移動させる もので、臓器の位置ずれ無しに 3 次元的サブトラクション CTアンジオグラムを作成する事を目的としている。ただし、 往と復とでは、たとえ同じスライス位置であっても僅かな差 (ミスレジストレーション)が生じる。人体ファントムで評価 したところ、骨部やその近傍以外ならば、ミスレジストレー ションはごく軽微であった。

\section{【方法】}

撮影のタイミングを図1に示す。ます、動きの少ない頭部 で染め分けを試みた。往：造影前、復：造影後となるように、 造影剤 $80 \mathrm{cc}$ を $3 \mathrm{cc} / \mathrm{s}$ で注入、造影開始5秒後からスライス厚 $5 \mathrm{~mm}$ 、寝台移動 $7.5 \mathrm{~mm}$ /回転、往 15 秒復 15 秒で撮影した。次 に、腹部で 1 回の呼吸停止下で動脈相と門脈相の描出を行な った。撮影は動脈と門脈の増強効果が交差する時点で寝台の 移動方向が反転するようにした。造影剂 $60 \mathrm{cc}$ を $6 \mathrm{cc} / \mathrm{s}$ で注入後、 $35 \mathrm{cc} 3 \mathrm{cc} / \mathrm{s}$ で追加し、造影開始 25 秒後からスライス厚 $5 \mathrm{~mm}$ 、 寝台移動 $5 \mathrm{~mm} /$ 回転、往15秒復15秒で撮影した。

\section{【結果】}

頭部では時相の染め分けができた(図 2)。頭蓋内は血管の みが描出された。また、サブトラクション像からの3D構成 ではノイズに埋もれていた細かい血管も抽出できた。腹部で は動脈相、門脈相をそれぞれとらえる事ができた(図3)。缄 器については位置ずれがほとんど無かった。サブトラクショ ン像では、動脈、門脈がそれぞれ白くはっきり観察でき、さ らにサブトラクション像からの3D構成では動脈のみ、門脈 のみがそれぞれ描出できた。

\section{【まとめ】}

(1)体表面等に扔いて、ミスレジストレーションが認められ たが、位置ずれの少ないサブトラクションが可能であった。 (2)造影のタイミングを工夫した、1回の造影往復へリカルス キャンによって、息止めの間の短い時間内でふたつの時相を 撮影できた。こうして得た画像を用いてサブトラクションを すると、動脈相、門脈相の分離がより正確に行なえた。

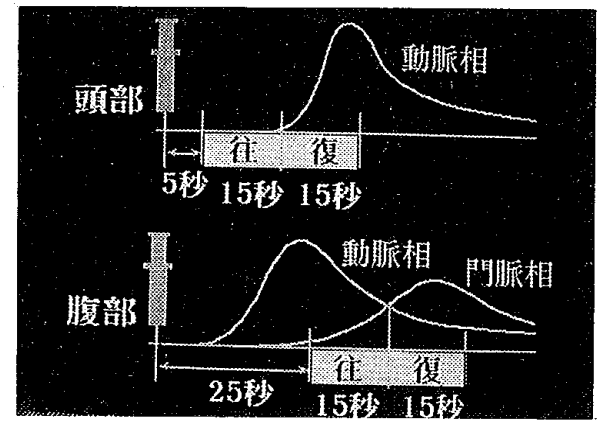

図 1.撮影のタイミング

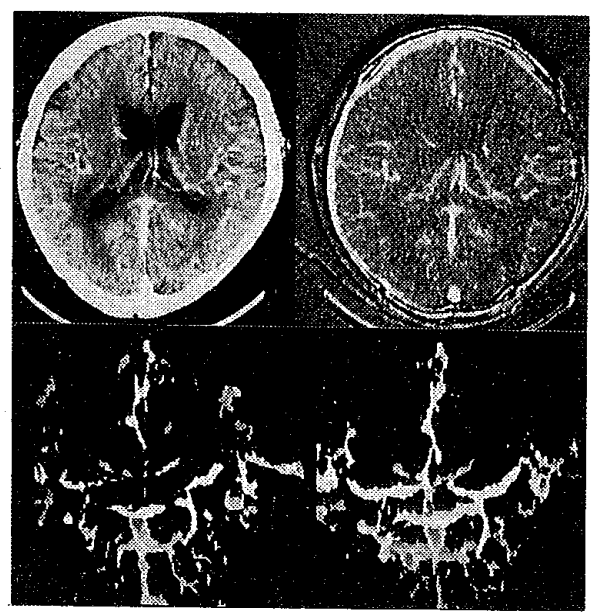

図2、頭部での䊅果

左上: 動脈相

右上: サフトラクション像(動脈相 - 単純) 左下: 動脈相からの3D棈成

右下:サブトラクション像からの3D構成

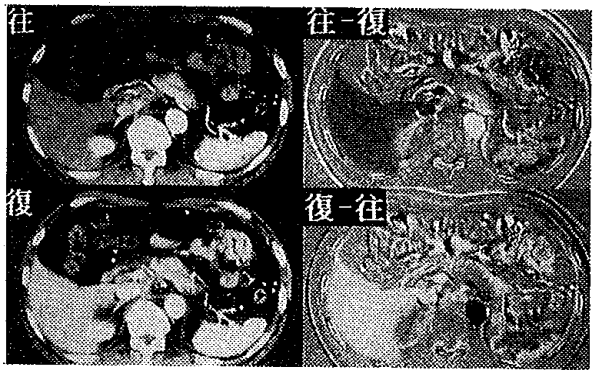

図 3、腹部での結果

左上: 動脈相 右上: 動脈相 - 門脈相 左下: 門脈相 右下: 門脈相 - 動脈相 